\title{
The effect of fishmeal on the digestion of grass silage by growing cattle
}

\author{
By D. E. BEEVER AND M. GILL* \\ AFRC Institute for Grassland and Animal Production, Hurley Research Station, Hurley, \\ Maidenhead, Berks SL6 5LR \\ AND J. M. DAWSON AND P. J. BUTTERY \\ Department of Applied Biochemistry \& Food Science, School of Agriculture, University of \\ Nottingham, Sutton Bonington, Loughborough, Leics LE12 5 RD
}

(Received 1 August 1989 - Accepted 30 November 1989)

\begin{abstract}
The effect of two levels of fishmeal substitution (50 (FM1) and 150 (FM2) g/kg) of a grass silage control diet $(C)$ on the rumen digestion of organic matter and nitrogen, and the small intestinal disappearance of amino acids was examined in young growing cattle each equipped with simple PVC cannulas in the dorsal sac of the reticulo-rumen, the proximal duodenum and the terminal ileum. The silage was a primary growth of perennial ryegrass (Lolium perenne) ( + formic acid) with a total $N$ content of $22 \mathrm{~g} / \mathrm{kg}$ dry matter (DM) (diet C). Fishmeal substitution increased this to 26 (diet FM1) and 34 (diet FM2) g/kg DM. On diets $C$ and FM1, approximately 0.71 of digestible organic matter intake was apparently digested in the rumen, but this was significantly $(P<0.05)$ reduced on diet FM2 $(0.60)$. Whilst duodenal flows of non-ammonia $\mathrm{N}$ and total amino acids were significantly $(P<0.01)$ increased at the highest level of fishmeal inclusion only, the synthesis of microbial $N$ was significantly $(P<0.001)$ reduced by fishmeal inclusion, and feed $\mathbf{N}$ degradability declined progressively in response to increased fishmeal. Both levels of fishmeal addition caused a significant $(P<0.05)$ reduction in the fractional outflow rate of water from the rumen, and on the highest level of fishmeal significant $(P<0.05)$ increases in rumen ammonia concentration and rumen propionate molar proportions were observed. The net effect of the highest level of fishmeal substitution was to increase amino acid absorption from the small intestine by 0.47 compared with the control diet $(P<0 \cdot 05)$, but due to an elevated ileal flow of amino acid no such effect was detected at the lowest level of fishmeal substitution. Composition of the absorbed amino acid fraction was relatively unaffected by the treatments imposed, despite large changes in the composition of the duodenal protein. The apparent non-linearity of response to fishmeal substitution is discussed and the amino acid supply findings are compared with the protein retention findings obtained in an earlier study by Gill $e$ et al. (1987). By two methods of calculation it was estimated that the amino acid $N$ fraction disappearing from the small intestine was utilized with an efficiency of between 0.51 and 0.53 and no apparent effects due to diet or level of amino acid supply were detected.
\end{abstract}

Fishmeal: Grass-silage digestion: Cattle

The rate of live-weight gain in young growing cattle offered grass-silage diets can be quite variable and often below theoretical expectations. Poor levels of voluntary feed consumption and an impairment in protein supply have been suggested as possible explanations, supported by the studies of Lonsdale (1976) and Gill et al. (1987) which demonstrated high fat:protein ratios in cattle receiving grass silage only as feed. When Thomson et al. (1981) in conjunction with C. R. Lonsdale and D. J. Thomson (unpublished results) and Gill et al. (1987) attempted to enhance protein supply either by the use of a

* Present address: ODNRI, Central Ave., Chatham Maritime, Chatham, Kent ME4 4TB. 
formaldehyde-containing silage additive or fishmeal supplementation respectively, significant improvements in protein retention were observed whilst levels of fat accretion declined or remained unchanged.

The objective of the present experiment was to quantify the effect of two levels of fishmeal substitution on nutrient digestion and supply using, similar animals and the same grass silage as described by Gill et al. (1987). The diets were offered in two separate feeds each day and the estimates of amino acid disappearance from the small intestine were related to the protein anabolic effects observed by Gill et $x$ l. (1987). In a parallel study, Dawson et al. (1988) used the same silage to examine protein metabolism in the rumen, but owing to the experimental procedures used, the diets were offered hourly by means of automatic feeders.

A preliminary report on part of the experiment presented here has already been published (Beever et al. 1987).

\section{MATERIALS AND METHODS \\ Preparation of diets}

A primary growth of perennial ryegrass (Lolium perenne $\mathrm{cv}$. Cropper) was cut on 24 and 25 May 1984 and harvested, after a short wilt (to $220 \mathrm{~g}$ dry matter (DM)/kg), with a precision-chop forage-harvester. Formic acid (3.3 litres/tonne fresh grass) was applied at the time of harvesting and the grass was ensiled in a concrete-walled clamp silo. The silage for the production study (Gill et al. 1987) was removed frcm the silo from 13 to 23 weeks after ensiling. During this time, sufficient silage for the present experiment was removed from the clamp and placed into $25 \mathrm{~kg}$ sacks before storin $;$ at $-20^{\circ}$. The silage was held frozen for approximately 2 months before the start of the present experiment, at which stage sufficient feed was removed on a daily basis and gently thawed for approximately $48 \mathrm{~h}$ before feeding. The three experimental diets comprised silage alone (C) or with inclusion of fishmeal (Provimi 66; British White Fish Meals Ltd) equivalent to 50 (FM1) and 150 (FM2) $\mathrm{g}$ fresh weight $/ \mathrm{kg}$ total diet DM with all diets fed at $24 \mathrm{~g} \mathrm{DM} / \mathrm{kg}$ live weight. The fishmeal and silage were thoroughly mixed just before feeding.

\section{Animals}

Six Friesian steers (initially $120 \mathrm{~kg}, 5-6$ months old) were used. Before the experiment, each animal was prepared, in two stages, with a PVC cannula (i.d. $38 \mathrm{~mm}$ ) into the dorsal sac of the reticulo-rumen and PVC ' $T$ '-piece cannulas (i d. $20 \mathrm{~mm}$ ) into the proximal duodenum anterior to the bile duct, and in the terminal ileum, using techniques previously described by Beever et al. (1978).

During the post-operative recovery period and between measurement periods when diet change-overs were effected, all animals were housed in incividual pens, and transferred to metabolism crates (Cammell, 1977) for each measurement period. At all times, the animals were held in a well-ventilated, continuously illuminated environment with free access to fresh water and mineral blocks. The animals were weighed before and at the end of each measurement period to allow intake levels to be adjusted according to individual animal live weights.

\section{Experimental design}

The experiment comprised two $3 \times 3$ Latin squares. The a nimals were allocated at random to each square and, subsequently, to the three dietary treatments within each square. Each experimental period lasted approximately 5 weeks, i.e. a 2 week adaptation period to the 
diets, when the animals were offered equal feeds at 09.00 and 17.00 hours each day, followed by a 3 week measurement period when equal feeds were offered at $12 \mathrm{~h}$ intervals (09.00 and 21.00 hours). Refusals, if any, were removed daily at 08.30 hours and dry weights were recorded.

\section{Experimental procedures}

During each experimental measurement period, total faecal output was collected and weighed daily for $7 \mathrm{~d}$ and a subsample, bulked over the whole period was obtained for each animal. Subsequently each animal received an intrarumen dose of CrEDTA $(100 \mathrm{ml} ; 3300$ $\mu \mathrm{g} \mathrm{Cr} / \mathrm{g})$ at 09.00 hours and strained rumen samples $(15 \mathrm{ml})$ were taken hourly over the next $12 \mathrm{~h}$ to estimate rumen fractional outflow rate of water. The following day Dacron bags were placed in the rumen with each bag containing fresh experimental silage equivalent to approximately $5 \mathrm{~g} \mathrm{DM}$. Rates and extent of silage organic matter (OM) and nitrogen digestion were estimated by sequential removal of bags over the next $48 \mathrm{~h}$ (Siddons et al. $1982 a$ ). On the following day strained rumen contents $(15 \mathrm{ml})$ were taken from each animal at 30 -min intervals between 09.00 and 21.00 hours using automatic sampling apparatus (R. T. Evans, unpublished), and acidified with $2.5 \mathrm{M}$-sulphuric acid. Subsequently, ytterbium acetate (YbAc; $50 \mathrm{mg} \mathrm{Yb/kg} \mathrm{DM} \mathrm{intake)} \mathrm{and} \mathrm{CrEDTA} \mathrm{(120} \mathrm{mg} \mathrm{Cr} / \mathrm{kg}$ DM intake) were infused $(20 \mathrm{ml}$ infusate $/ \mathrm{h})$ continuously into the rumen using separate infusion lines. After maintenance of the infusions for $7 \mathrm{~d}$, samples of ileal contents were collected hourly from each animal between 09.00 and 21.00 hours on two successive days (Beever et al. 1971). ${ }^{15} \mathrm{~N}$-labelled ammonium sulphate $\left(95 \%\right.$ enriched; $\left.1 \mathrm{~g}\left({ }^{15} \mathrm{NH}_{4}\right)_{2} \mathrm{SO}_{4} / \mathrm{d}\right)$ was then added to each $\mathrm{Yb}$-containing infusate and the infusions were maintained for $2 \mathrm{~d}$ before collection of duodenal digesta and for a further $2 \mathrm{~d}$ until digesta collection was completed. Duodenal digesta were collected using the automatic sampling apparatus described by Evans et al. (1981), with $2 \times 24 \mathrm{~h}$ collections being attempted for each animal. Following completion of duodenal sampling, diet change-overs were commenced and feed levels were adjusted according to live weight.

\section{Sample preparation and analysis}

Samples of the silage and fishmeal were taken daily and DM determined weekly by oven drying to allow offered feed levels to be adjusted. During the faecal and digesta collection periods fresh samples of both silage and fishmeal were frozen, subsequently freeze-dried, and ground before chemical analysis. After thorough mixing, representative subsamples of the accumulated faecal samples were oven-dried to determine DM content, whilst a further portion was freeze-dried, ground and retained for analysis.

Accumulated samples of daily ileal and duodenal digesta were thoroughly mixed and centrifuged at $2000 \mathrm{rev} / \mathrm{min}$ for $10 \mathrm{~min}$ to provide samples of centrifuged digesta (residue), in addition to representative samples of whole digesta. These were subsequently freezedried, ground and retained for analysis. Finally, the supernatant fraction obtained from duodenal digesta after removal of the residue was centrifuged at $20000 \mathrm{~g}$ for $30 \mathrm{~min}$ and after two washes, with glass-distilled water, the resultant microbial fraction was freezedried before analysis.

Following removal from the rumen, the Dacron bags were washed thoroughly in cold water, oven dried for $24 \mathrm{~h}$ and the dry weight of the contents recorded. Subsequently these were ground and retained for analysis.

All rumen samples were stored at $-20^{\circ}$ until required for analysis of $\mathrm{Cr}$, volatile fatty acid or ammonia concentrations (Beever et al. 1985; Siddons et al. 1985a).

Analytical procedures for estimation of silage constituents and fishmeal composition were as described by Gill et al. (1987). OM, total $\mathrm{N}$, ammonia $\mathrm{N}, \mathrm{Yb}, \mathrm{Cr}$ and ${ }^{15} \mathrm{~N}$ contents of 
faecal, ileal, duodenal and microbial samples were analysed (as appropriate) using previously described techniques (Beever et al. 1978, 1985; Siddons et al. 1982a, b, 1985b). Contents of individual amino acids in whole and centrifuged duodenal and ileal samples were determined by cation exchange chromatography using an LKB 4400 amino acid analyzer operating with sodium buffers, after hydrolysis under $\mathrm{N}_{2}$ with $7.5 \mathrm{ml} 6 \mathrm{M}$ hydrochloric acid using between 100 and $200 \mathrm{mg}$ sample. Cystine and methionine contents were determined after oxidation with formic acid ( $10 \mathrm{vol}$. hydrogen peroxide, $80 \%$ formic acid, $5 \mathrm{mg}$ phenol/ml) without $\mathrm{N}_{2}$, before the hydrolysis step.

\section{Calculation of results and statistical cinalysis}

Estimates of nutrient flow to the duodenum and the terminal ileum were obtained with $\mathrm{Yb}-\mathrm{Cr}$ as dual-phase markers as proposed by Faichney (1975), using whole digesta and centrifuged digesta as the two distinct digesta phases. Estimates of microbial $\mathrm{N}$ synthesis were obtained by comparison of the ${ }^{15} \mathrm{~N}$ enrichments of microbial $\mathrm{N}$ and total nonammonia $\mathrm{N}$ in duodenal digesta according to the procedures of Siddons et al. (1982a). The estimate of duodenal non-microbial $\mathrm{N}$ was further fractionated into endogenous and undegraded dietary $\mathrm{N}$ by application of a standard endogenous $\mathrm{N}$ flow of $2.98 \mathrm{~g} / \mathrm{kg} \mathrm{OM}$ intake (Bartram, 1987). Fractional outflow rate of water from the rumen was estimated from a $\log$ plot of $\mathrm{Cr}$ concentration against time according to Warner \& Stacy (1972), whilst the rates and extents of $\mathrm{OM}$ and $\mathrm{N}$ digestion in the rumen were estimated by fitting the values obtained for nutrient disappearance from the Dacron bags $v$. time to the Mitshcherlich equation, according to the procedures of Ørskov \& McDonald (1979).

All results were subjected to analysis of variance of a two $3 \times 3$ Latin square design with one animal per sequence. There were $8 \mathrm{df}$ associated with error term but due to missing values, error df were reduced to either 5 or 6 . In Latin square designs it is a common problem that pairwise interactions among columns, rows and treatments enter the error term and, thus, can make error variance too large for variance-ratio test of treatment effects. However, if the row and column effects are large then this overestimation of the error terms is unimportant (Wilk \& Kempthorne, 1957). We found this to be the case in the analysis of data reported here. Whilst the use of additive anclysis of variance model appears to be justified, a further test of additivity (Tukey, 1955) was undertaken to establish the validity of an additive model:

$$
Y_{i j k}=u+a_{i}+p_{j}+t_{k}+e_{i j k},
$$

where $u$ is the overall mean and $a_{i}, p_{j}$ and $t_{k}$ are the animal, period and treatment effects respectively and $e_{i j k}$ are normally and independently distributed with zero mean and constant variance. We used the procedure outlined by Rojas (1973) which is equivalent to the Tukey (1955) and Snedecor \& Cochran (1969) methods but computationally easier to use. Rojas (1973) used the model:

$$
y=u+a_{i}+p_{j}+t_{k}+e x_{i j k}+e_{i j k}
$$

where $x_{i j k}$ is a covariate constructed from the estimates of $a, p$ and $t$ from the analysis of variance based on the additive model, i.e. ${ }_{i} x_{j k}=(\hat{a} \hat{p}+\hat{a} \hat{t}+\hat{p} \hat{t})$. The test of additivity then reduces to the test of significance of regression coefficient $\hat{\theta}$ in an analysis of covariance.

It was found that the analyses based on the additive model were satisfactory and even when $\hat{\theta}$ approached significance $(P<0.01)$ the conclusions reached were unaltered. Treatment contrasts were used to test the effect of fishmea compared with the control and also among fishmeal levels. The difference among the fishmeal levels was small, thus indicating non-linear response to fishmeal substitution. 
Table 1. Chemical composition of the silage ( $\mathrm{g} / \mathrm{kg}$ dry matter $(D M))$

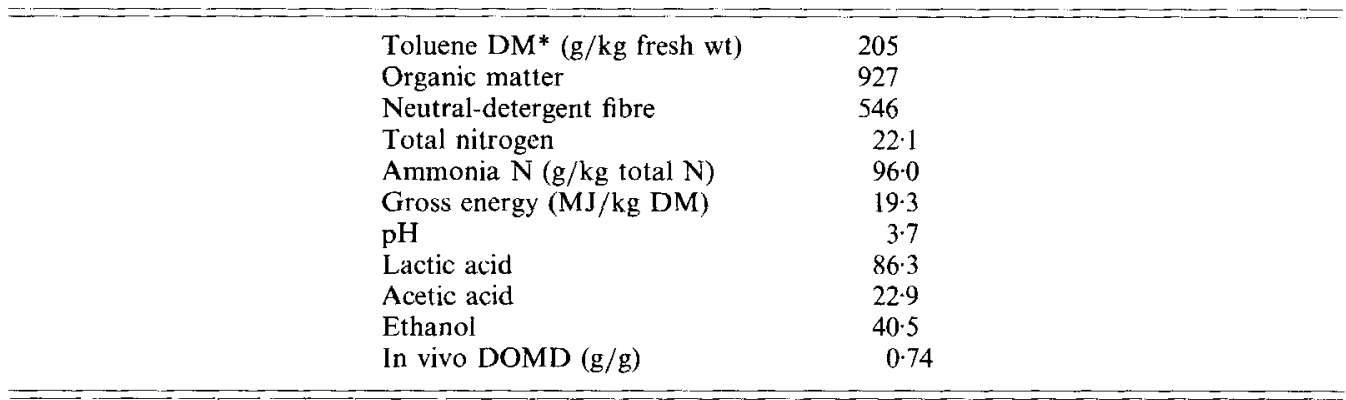

DOMD, digestible organic matter digested.

* Corrected for ethanol content.

\section{RESULTS}

The composition of the silage is presented in Table 1. From an assessment of the contents of fermentation acids, $\mathrm{pH}$ and ammonia $\mathrm{N}$ content (as a proportion of total $\mathrm{N}$ ) it appeared that the silage was well-preserved, whilst estimates of in vivo digestible OM and neutraldetergent fibre content indicated that the nutritive value of the silage was high, although total $\mathrm{N}$ content was quite low.

The fishmeal had an OM content of $837 \mathrm{~g} / \mathrm{kg} \mathrm{DM}$ and an $\mathrm{N}$ content of $105 \mathrm{~g} / \mathrm{kg} \mathrm{DM}$, with the overall effect of fishmeal substitution being to increase total dietary $N$ to 26.2 and $34.5 \mathrm{~g} / \mathrm{kg}$ DM (diets FM1 and FM2 respectively).

Values in Table 2 refer to the rumen fermentation characteristics with the three diets. The first level of fishmeal inclusion (diet FM1) had no effect on rumen ammonia concentration, but at the higher level (diet FM2) a significant $(P<0.05)$ increase was observed, whilst both levels of fishmeal caused a significant $(P<0.05)$ decline in the fractional outflow rate of water from the rumen. In situ degradation studies indicated that silage $O M$ and total $N$ potential degradability were high (mean values 0.89 and 0.92 respectively) and not significantly affected by fishmeal inclusion. Similarly the rates of $\mathrm{OM}$ and $\mathrm{N}$ degradation were not significantly affected by fishmeal inclusion, although it should be noted that both rates were lower with diet FM1 compared with diets $\mathrm{C}$ and FM2. Total volatile fatty acid concentrations, representing a mean value over the $12 \mathrm{~h}$ sampling period were unaffected by the treatments, and equally diet FM1 had no effect on volatile fatty acid molar proportions compared with diet $\mathrm{C}$. In contrast, with diet FM2, molar proportion of propionate increased whilst acetate decreased compared with the other two diets. Although this difference was not significant, the overall effect was a reduction in the ratio of acetate + butyrate :propionate from 3.81 (diets C and FM1) to 3.27 (diet FM2).

This observation is further illustrated in Fig. 1 where the effect of the two levels of fishmeal inclusion on rumen molar proportions of propionate during one feeding cycle is presented. In response to feeding ( 09.00 hours) all diets showed a pronounced increase in propionate molar proportion, but the values appeared to be higher at all times with diet FM2 compared with diets $\mathrm{C}$ and FM1, with the magnitude of the difference increasing at 3-4 h after feeding.

Values in Table 3 indicate the effects of fishmeal inclusion on $\mathrm{OM}$ and $\mathrm{N}$ digestion and total amino acid supply. OM intakes were similar for all three diets, but whilst OM digestibility was high on the control silage, fishmeal supplementation caused small but significant $(P<0.05)$ increases (diet C 0.794 , diets FMI and FM2 0.818). The quantity of OM entering the small intestine was similar with diets C and FM 1 (mean $1.61 \mathrm{~kg} / \mathrm{d}$ ), but 
Table 2. The effect of fishmeal on rumen fermentation characteristics in young cattle offered a basal diet of grass silag,e

\begin{tabular}{|c|c|c|c|c|}
\hline $\operatorname{Diet}^{*} \ldots$ & Control & FMI & FM2 & $\begin{array}{c}\mathrm{SE} \\
\text { of mean }\end{array}$ \\
\hline Rumen ammonia nitrogen concentration (mg/l) & 113 & 109 & 149 & $5 \cdot 2$ \\
\hline Fractional outflow rate of water from the rumen $(h)$ & $0 \cdot 19$ & $0 \cdot 14$ & $0 \cdot 12$ & 0011 \\
\hline $\begin{array}{l}\text { Silage digestion characteristics: } \\
\text { Potential degradability }(\mathrm{g} / \mathrm{g})\end{array}$ & & & & \\
\hline $\begin{array}{l}\mathrm{OM} \\
\mathrm{N}\end{array}$ & $\begin{array}{l}0.88 \\
0.91\end{array}$ & $\begin{array}{l}\text { 1) } \cdot 90 \\
\text { 1) } 93\end{array}$ & $\begin{array}{l}0.90 \\
0.93\end{array}$ & $\begin{array}{l}0-012 \\
0 \cdot 008\end{array}$ \\
\hline $\begin{array}{l}\text { Rate of degradation }(/ \mathrm{h}) \\
\text { OM } \\
\mathrm{N}\end{array}$ & $\begin{array}{l}0.072 \\
0 \cdot 16\end{array}$ & $\begin{array}{l}3 \cdot 061 \\
3 \cdot 11\end{array}$ & $\begin{array}{l}0 \cdot 077 \\
0 \cdot 15\end{array}$ & $\begin{array}{l}0.0054 \\
0.0015\end{array}$ \\
\hline Rumen VFA concentration ( $\mathrm{mmol} / 1)$ & $80 \cdot 4$ & $81 \cdot 3$ & $81 \cdot 0$ & $3 \cdot 10$ \\
\hline $\begin{array}{l}\text { Molar proportions of rumen VFA: } \\
\text { Acetate } \\
\text { Propionate } \\
\text { Butyrate }\end{array}$ & $\begin{array}{l}0 \cdot 68 \\
0 \cdot 21 \\
0 \cdot 11\end{array}$ & $\begin{array}{l}0 \cdot 69 \\
0 \cdot 21 \\
0 \cdot 11\end{array}$ & $\begin{array}{l}0.67 \\
0.23 \\
0 \cdot 10\end{array}$ & $\begin{array}{l}0.016 \\
0.011 \\
0-006\end{array}$ \\
\hline
\end{tabular}

FM1, $50 \mathrm{~g}$ fishmeal $/ \mathrm{kg}$ total dry matter; FM2, $150 \mathrm{~g}$ fishmeal $/ \mathrm{kg}$ total cry matter; OM, organic matter; VFA, volatile fatty acids.

* For details, see p. 490 and Table 1.

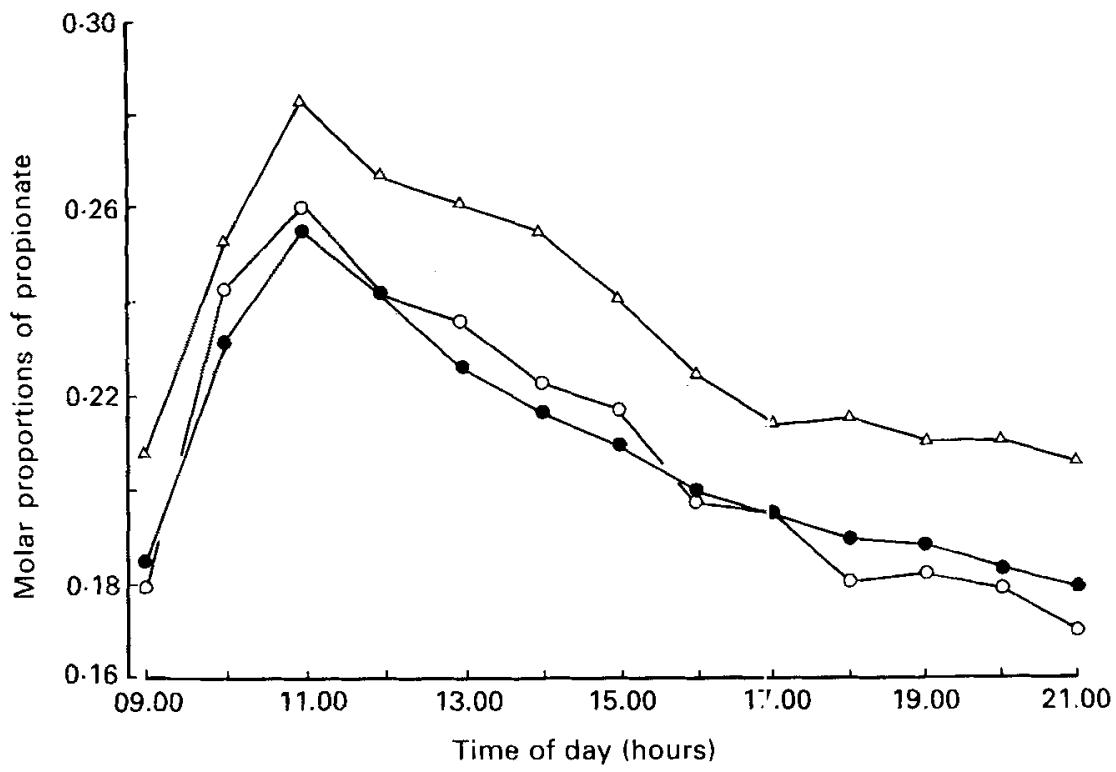

Fig. 1. The effect of fishmeal on the molar proportion of propionic acid in the rumen of cattle consuming a grass silage diet. (O), Control diet; (O), diet FM1 (50 g fishmeal $/ \mathrm{kg}$ total dry matter; ( $\triangle$ ), diet FM2 (150 g fishmeal $/ \mathrm{kg}$ total dry matter). Each data point is the mean observation for six animals. For details of diets see p. 490 and Table 1 .

approximately $20 \%$ higher with diet FM2. Consequently only 0.6 of the digestible OM consumed on this diet was apparently digested in the rumen compared with 0.71 and 0.72 for the other two diets $(P<0.05)$. With diet $\mathrm{C}$, approximately 0.50 of duodenal $\mathrm{OM}$ was digested in the small intestine, but the extent of digestion with diet FM1 was reduced (0.33) 
Table 3. The mean quantities of organic matter $(O M ; \mathrm{kg} / \mathrm{d})$ and total nitrogen (or nonammonia $N ; \mathrm{g} / \mathrm{d}$ ) consumed, entering and leaving the small intestine and in the faeces of young cattle consuming silage (control) and fishmeal-containing silage diets. Values for total quantities of amino acids $(\mathrm{g} / \mathrm{d})$ entering and leaving the small intestine, and absorbed from the small intestine are also presented

\begin{tabular}{|c|c|c|c|c|}
\hline $\operatorname{Diet}^{*} \ldots$ & Control & FMl & FM2 & $\begin{array}{c}\text { SE } \\
\text { of mean }\end{array}$ \\
\hline \multicolumn{5}{|l|}{ Organic matter: } \\
\hline Consumed & 3.79 & 3.78 & 3.79 & 0.034 \\
\hline Entering small intestine & 1.62 & 1.59 & 1.93 & 0.167 \\
\hline Leaving small intestine & 0.82 & 1.07 & 0.80 & 0.070 \\
\hline In faeces & 0.78 & $0 \cdot 71$ & 0.67 & 0.019 \\
\hline Apparent digestibility (g/kg DM intake) & 0.794 & 0.812 & 0.823 & 0.0036 \\
\hline Proportion of digestible OM digested in rumen & 0.721 & 0.713 & 0.596 & 0.0496 \\
\hline \multicolumn{5}{|l|}{ Total N: } \\
\hline Consumed & 90 & 108 & 143 & 1.9 \\
\hline Entering small intestine $\dagger$ & 106 & 111 & 140 & $5 \cdot 2$ \\
\hline Leaving small intestine & 36 & 48 & 43 & $2 \cdot 4$ \\
\hline In faeces & 26 & 27 & 28 & 0.63 \\
\hline \multicolumn{5}{|l|}{ Total amino acids: } \\
\hline Entering small intestine & 462 & 497 & 656 & 37.5 \\
\hline Leaving small intestine & 137 & 191 & 177 & 13.7 \\
\hline Absorbed & 326 & 306 & 479 & 25.9 \\
\hline
\end{tabular}

DM, dry matter; FMI, $50 \mathrm{~g}$ fishmeal $/ \mathrm{kg}$ total DM; FM2, $150 \mathrm{~g}$ fishmeal $/ \mathrm{kg}$ total DM.

* For details, see p. 490 and Table 1 .

$\dagger$ Non-ammonia $\mathrm{N}$.

despite a similar duodenal OM supply. In contrast, apparent digestibility of duodenal OM in the small intestine for diet FM2 was almost 0.60, and despite the higher duodenal OM supply on this diet, ileal OM flow was identical to that of diet $\mathrm{C}$, and both were significantly $(P<0.05)$ lower than that of $\operatorname{diet}$ FM1.

Fishmeal inclusion increased total N intake by 18 (diet FM1) and 53 (diet FM2) g/d but this increase was not fully reflected in the estimates of duodenal non-ammonia $\mathrm{N}$ supply and only on diet FM2 was a significant increase observed $(140$ v. $109 \mathrm{~g} / \mathrm{d}$ (diets $\mathrm{C}$ and FM1), $P<0.01$ ). With diets $\mathrm{C}$ and FM2, small-intestinal availabilities of duodenal nonammonia $N$ (measured by reference to ileal total $N$ ) were 0.66 and 0.68 respectively, compared with 0.57 for diet FM1, with ileal N flows being significantly $(P<0.05)$ higher for diet FM1 compared with diets $\mathrm{C}$ or FM2. Hind-gut digestion of $\mathrm{N}$ was greatest with diet FM1, and consequently faecal $\mathrm{N}$ outputs were similar for all diets. In response to fishmeal inclusion, total amino acid flows into the small intestine increased by $8(P>0.05)$ and $42 \%(P<0.05)$ with diets FM1 and FM2 respectively compared with diet $\mathrm{C}$. However, both fishmeal-containing diets showed increased quantities of total amino acids leaving the small intestine, and small-intestinal loss of total amino acids was only increased on diet FM2 $(P<0.05)$. Mean apparent digestibility of duodenal amino acids in the small intestine were $0.71,0.62$ and 0.73 for diets $C, F M 1$ and FM2 respectively.

Both fishmeal treatments significantly $(P<0-05)$ reduced microbial $\mathrm{N}$ synthesis by an average of almost $12 \%$ (Table 4 ), whilst the estimated quantities of undegraded dietary $\mathrm{N}$ flowing to the small intestine increased significantly at both levels of inclusion $(P<0.001)$. Consequently, degradability of total dietary $N$ which was high with diet $C(0.83 \mathrm{~g} / \mathrm{g})$ declined progressively in response to the lower $(P<0.001)$ and higher $(P<0.001)$ levels of 
Table 4. The mean quantities $(\mathrm{g} / \mathrm{d})$ of total, microbial, undegraded, and ammonia nitrogen flowing into the small intestine of young cattle consuming silage (control) or fishmealcontaining silage diets, the apparent degradabilities of feed $N(\mathrm{~g} / \mathrm{g})$ and the efficiencies of rumen microbial $\mathrm{N}$ synthesis $(\mathrm{g} / \mathrm{kg}$ organic matter $(O M)$ apparently $(O M A D R)$ or truly $(O M T D R)$ digested in the rumen)

\begin{tabular}{|c|c|c|c|c|}
\hline Diet*... & Control & FM1 & FM2 & $\begin{array}{c}\text { SE } \\
\text { of mean }\end{array}$ \\
\hline Totai N & $113 \cdot 0$ & $118 \% 8$ & $148 \cdot 9$ & $5 \cdot 17$ \\
\hline Ammonia $N$ & 6.9 & 7.5 & $8 \cdot 8$ & 0.21 \\
\hline Microbial N & 80.6 & $69 \cdot 9$ & $73 \cdot 2$ & $2 \cdot 41$ \\
\hline Undegraded dietary $N$ & $14 \cdot 9$ & $31) \cdot 2$ & $57 \cdot 1$ & $2 \cdot 46$ \\
\hline Endogenous $\mathrm{N} \dagger$ & $11 \cdot 3$ & $11 \cdot 3$ & $11 \cdot 3$ & - \\
\hline \multicolumn{5}{|l|}{ Feed $N$ degradability } \\
\hline Total dietary $\mathrm{N}$ & $0 \cdot 83$ & $3 \cdot 72$ & $0 \cdot 60$ & 0.0175 \\
\hline Fishmeal supplement & & $3 \cdot 28$ & $0 \cdot 35$ & \\
\hline \multicolumn{5}{|c|}{ Efficiency of microbial $\mathrm{N}$ synthesis: } \\
\hline OMADR & $36 \cdot 5$ & $31 \cdot 9$ & $39 \cdot 4$ & $4 \cdot 21$ \\
\hline OMTDR & $26 \cdot 6$ & $24 \cdot 5$ & $28 \cdot 7$ & 4.43 \\
\hline
\end{tabular}

FM1, $50 \mathrm{~g}$ fishmeal $/ \mathrm{kg}$ total dry matter; FM2, $150 \mathrm{~g}$ fishmeal $/ \mathrm{kg}$ total dry matter

* For details, see p. 490 and Table 1

+ Endogenous $\mathrm{N}$ assumed from Bartram (1987).

+ Assuming a microbial N content of $101 \cdot 8$ (control) and 94.9 (FM1 and FM2), g/kg OM (Dawson et al. 1988).

fishmeal supplementation, and a significant $(P<0 \cdot 001)$ difference between the two fishmeal diets was also observed. If it is assumed that the degradability of the silage was unaffected by the inclusion of fishmeal (i.e. remained at $0.83 \mathrm{~g} / \mathrm{g}$ ) then estimates of fishmeal degradability of 0.28 and $0.35 \mathrm{~g} / \mathrm{g}$ (diets FM1 and FM2 respectively) can be obtained. It may be concluded that on diet FM2, the increase in duoder al non-ammonia $\mathrm{N}$ supply was wholly attributable to an increased passage of undegraded dietary $\mathrm{N}$.

Efficiency of microbial $\mathrm{N}$ synthesis in relation to the quartity of $\mathrm{OM}$ apparently digested in the rumen (OMADR) ranged from 32 to $39 \mathrm{~g} / \mathrm{kg}$ with nc significant or consistent effects due to diet. When related to OM truly digested in the rumen, values were lower (24-29 $\mathrm{g} / \mathrm{kg}$ ) and again not apparently related to dietary treatments.

Values presented in Table 5 relate to the duodenal and ileal supply of individual amino acids, and the composition of the amino acids which disappeared from the small intestine for the three diets.

Fishmeal at the lowest level of inclusion marginally increased the duodenal supply of all amino acids compared with the control diet whereas with diet FM2, all amino acid flows were substantially increased compared with the other two ciets. Comparison of the control diet against the two fishmeal diets indicated significant $(P<0.05)$ increases in duodenal flow of all amino acids except valine and phenylalanine, whilst comparison of diet FM2 with diet FM 1 revealed significant $(P<0.05)$ increases in all amino acids except methionine and arginine.

Despite the differences observed in the duodenal flow of amino acids, amino acid flows at the ileum were, in most instances, only marginally higher on the fishmeal-containing diets compared with the control, and no statistically significant effects were detected apart from lysine (diet $\mathrm{C} v$. fishmeal-containing diets (FM1 and FM2); $P<0 \cdot 05$ ).

The effect of these changes on the composition of the c.pparently absorbed amino acid fraction was remarkably small. Both levels of fishmeal significantly $(P<0.05)$ reduced the content of isoleucine (diet C 57, diets FM1 and FM2 53), tyrosine (diet C 53, diets FM1 
Table 5. Mean quantities of individual amino acids $(\mathrm{g} / \mathrm{d})$ entering and leaving the small intestine of young cattle consuming silage (control) or fishmeal-containing silage diets, and the individual amino acid composition $(\mathrm{g} / \mathrm{kg})$ of the total amino acid fraction apparently absorbed from the small intestine

\begin{tabular}{|c|c|c|c|c|c|c|c|c|c|c|c|c|}
\hline \multirow[b]{2}{*}{$\operatorname{Diet}^{*} \ldots$} & \multicolumn{4}{|c|}{ Entering small intestine } & \multicolumn{4}{|c|}{ Leaving small intestine } & \multicolumn{4}{|c|}{ Apparently absorbed } \\
\hline & Control & FM1 & FM2 & $\begin{array}{l}\mathrm{SE} \text { of } \\
\text { mean }\end{array}$ & Control & FM1 & FM2 & $\begin{array}{l}\text { SE pf } \\
\text { mean }\end{array}$ & Control & FM I & FM2 & $\begin{array}{l}\mathrm{SE} \text { of } \\
\text { mean }\end{array}$ \\
\hline Aspartic acid & $50 \cdot 6$ & $54 \cdot 6$ & $71 \cdot 2$ & $4 \cdot 43$ & $14 \cdot 2$ & $20 \cdot 7$ & $19 \cdot 7$ & $1 \cdot 39$ & 113 & 113 & 106 & $3 \cdot 0$ \\
\hline Threonine & $26 \cdot 0$ & $28 \cdot 2$ & $35 \cdot 9$ & $2 \cdot 20$ & $9 \cdot 6$ & $12 \cdot 5$ & $11 \cdot 8$ & 0.69 & 48 & 51 & 49 & $2 \cdot 6$ \\
\hline Serine & $22 \cdot 3$ & $22 \cdot 5$ & $29 \cdot 3$ & 1.80 & $7 \cdot 7$ & $10 \cdot 9$ & $10 \cdot 0$ & 0.91 & 44 & 38 & 40 & $1 \cdot 6$ \\
\hline Glutamic acid & $60 \cdot 2$ & $66 \cdot 7$ & $88 \cdot 0$ & $5 \cdot 12$ & $18 \cdot 6$ & $26 \cdot 6$ & $23 \cdot 2$ & 1.66 & 129 & 130 & 136 & $2 \cdot 0$ \\
\hline Proline & $21 \cdot 0$ & $23 \cdot 8$ & $30 \cdot 3$ & $1 \cdot 46$ & $10 \cdot 2$ & $12 \cdot 6$ & $12 \cdot 1$ & 1.45 & 31 & 37 & 38 & $3 \cdot 5$ \\
\hline Glycine & $30 \cdot 0$ & $32 \cdot 6$ & $44 \cdot 2$ & $2 \cdot 94$ & $9 \cdot 3$ & $13 \cdot 0$ & $12 \cdot 1$ & 0.91 & 64 & 63 & 68 & $3 \cdot 4$ \\
\hline Alanine & $32 \cdot 6$ & $33 \cdot 5$ & $46 \cdot 7$ & 3.03 & $10 \cdot 6$ & $14 \cdot 5$ & $12 \cdot 9$ & 0.98 & 68 & 62 & 70 & $2 \cdot 2$ \\
\hline Valine & $29 \cdot 2$ & $29 \cdot 3$ & $38 \cdot 2$ & 2.23 & $8 \cdot 8$ & 10.7 & $10 \cdot 7$ & $1 \cdot 16$ & 61 & 61 & 59 & $3 \cdot 1$ \\
\hline Methionine & 9.8 & $12 \cdot 1$ & $13 \cdot 7$ & 0.92 & $2 \cdot 4$ & $2 \cdot 8$ & $2 \cdot 9$ & 0.65 & 23 & 30 & 23 & $2 \cdot 0$ \\
\hline Isoleucine & $25 \cdot 8$ & $27 \cdot 0$ & $34 \cdot 8$ & 1.95 & $7 \cdot 2$ & $10 \cdot 4$ & $9 \cdot 3$ & $0 \cdot 77$ & 57 & 54 & 53 & $0 \cdot 7$ \\
\hline Leucine & 38.9 & $43 \cdot 6$ & $61 \cdot 3$ & 3.95 & $12 \cdot 0$ & $17 \cdot 1$ & $15 \cdot 4$ & $1 \cdot 20$ & 85 & 87 & 95 & $4 \cdot 6$ \\
\hline Tyrosine & $21 \cdot 3$ & $21 \cdot 5$ & $27 \cdot 1$ & $1 \cdot 38$ & $4 \cdot 3$ & 6.7 & $6 \cdot 4$ & 0.74 & 53 & 48 & 44 & $1 \cdot 5$ \\
\hline Phenylalanine & $27 \cdot 5$ & $27 \cdot 7$ & 35.6 & $2 \cdot 08$ & $7 \cdot 5$ & $10 \cdot 7$ & $9 \cdot 7$ & 0.87 & 61 & 55 & 54 & 10 \\
\hline Lysine & 33.7 & $37 \cdot 5$ & $49 \cdot 2$ & $2 \cdot 67$ & 6.5 & $10 \cdot 1$ & $9 \cdot 8$ & $0 \cdot 63$ & 85 & 89 & 82 & $1 \cdot 2$ \\
\hline Histidine & $10 \cdot 4$ & 10.9 & $15 \cdot 5$ & $0 \cdot 84$ & $2 \cdot 9$ & $4 \cdot 4$ & $4 \cdot 2$ & 0.31 & 23 & 21 & 24 & $0 \cdot 4$ \\
\hline Arginine & $23 \cdot 1$ & $25 \cdot 9$ & $34 \cdot 5$ & 1.90 & $4 \cdot 7$ & 69 & $6 \cdot 8$ & 0.55 & 57 & 61 & 58 & 0.8 \\
\hline
\end{tabular}

FM1, $50 \mathrm{~g}$ fishmeal $/ \mathrm{kg}$ total dry matter; FM2, $150 \mathrm{~g}$ fishmeal $/ \mathrm{kg}$ total dry matter.

* For details see p. 490 and Table 1.

and FM2 46) and phenylalanine (diet C 61, diets FM1 and FM2 55) compared with diet $\mathrm{C}$, whilst alanine and histidine were significantly $(P<0.05)$ higher with diet FM 2 compared with diet FM1.

\section{DISCUSSION}

Nutrient supply on silages

There is considerable agreement between the findings obtained in the present study and the work reported by Thomson et al. (1981). The silage used by Thomson et al. (1981) had slightly lower $\mathrm{N}$ and higher neutral-detergent fibre contents than the silage used in the present experiment but the proportion of digestible $\mathrm{OM}$ which was apparently digested in the rumen was similar for both diets. Equally the two silages gave estimated small-intestinal flows of approximately $0.80 \mathrm{~g}$ amino acid $\mathrm{N} / \mathrm{g} \mathrm{N}$ intake. Rooke et al. (1987) on the other hand reported a lower value of $0.65 \mathrm{~g}$ amino acid $\mathrm{N} / \mathrm{g} \mathrm{N}$ intake for a silage with higher neutral-detergent fibre and lower $\mathrm{N}$ contents. With respect to the efficiency of microbial protein synthesis the comparison is less clear. Rooke et al. (1987) reported a value of 22 $\mathrm{g} / \mathrm{kg}$ OMADR and this agrees with other values obtained on silage diets, albeit mainly with sheep (Thomas, 1982), and supports the general view that overall microbial synthetic efficiency is low on such diets. In contrast, this present study gave a value of $37 \mathrm{~g} / \mathrm{kg}$ OMADR, whilst in the parallel study where Dawson et al. (1988) gave the same silage in equal hourly meals to cattle, a value of $31 \mathrm{~g} / \mathrm{kg}$ OMADR was obtained.

Reasons for such differences in the estimates of the efficiency of microbial protein synthesis are not immediately apparent. Both the results of the present study and those reported by Dawson et al. (1988) are considerably higher than general expectations, albeit much of the earlier information was obtained using sheep at maintenance levels of feed intake. In this 
regard, both animal species and level of intake may be influencing the efficiency of microbial protein synthesis. In a recent review, McAllan et al. (1987) concluded, from a detailed analysis of available data, that values for the efficiency of microbial protein synthesis tended to be higher with cattle than sheep for soth silage alone (cattle $27 \mathrm{~g}$ microbial N/ $\mathrm{kg}$ OM digested in the rumen, sheep $20 \mathrm{~g} / \mathrm{kg}$ ), and silage plus concentrate diets (cattle $33 \mathrm{~g} / \mathrm{kg}$, sheep $25 \mathrm{~g} / \mathrm{kg}$ ). Equally, in the study of Rooke et al. (1987) where a value of $22 \mathrm{~g} / \mathrm{kg}$ was reported, the cattle used were both non-pregnant and non-lactating and received only $12.5 \mathrm{~g} \mathrm{DM} / \mathrm{kg}$ body-weight, a level of intake approximating to 0.50 of that achieved in the present study. It is difficult to speculate further on the mechanisms involved, but such variation, which has been recognized but then often ignored, should provide a stimulus for future studies designed to understand, rather than simply quantify, $\mathrm{N}$ kinetics in the rumen of forage-fed cattle.

The highest level of fishmeal inclusion gave responses in nutrient supply which were more or less in line with expectations. Increased $\mathrm{N}$ intake gave an incremental response in duodenal non-ammonia $\mathrm{N}$ fiow of $0.64 \mathrm{~g} / \mathrm{g}$, which was wholly accounted for by an increased flow of undegraded dietary (presumably fishmeal) protein. At the same time fishmeal inclusion at the highest level caused significant increases in rumen ammonia concentrations. A similar response was reported by Dawson et al. (1988) for the same grass silage and the result has recently been confirmed by Ortigues et al. (1989) with fishmeal supplementation of straw-based diets. Both the present study and Dawson et al. (1988) found the highest level of fishmeal to increase duodenal amino acid supply by approximately $200 \mathrm{~g} / \mathrm{d}$, but unlike the present study, Dawson et al. (1988) found increases in both microbial protein synthesis and undegraded dietary $\mathrm{N}$ flow to the intestines. This led Dawson et al. (1988) to suggest that the efficiency of capture of rumen-degradable $\mathrm{N}$ (RDN) by the microbes had been increased due to an improvement in the quality of the RDN fraction available in the rumen. The in situ digestion studies undertaken in the present experiment suggested that the digestion rate of silage $\mathrm{N}$ was almost twice that of silage OM, from which the possibility of an imbalance between degraded $\mathrm{N}$ and $\mathrm{OM}$ for microbial synthesis with diet $\mathrm{C}$ can be inferred. However, in the present study diet $\mathrm{C}$ gave a value of 0.81 for the apparent efficiency of microbial capture of RDN, and values on the fishmeal diets ( 0.79 and 0.78 , diets FM1 and FM2 respectively) suggest that there were no apparent improvements due to a possible improvement in the composition of the RDN fraction. In contrast, Dawson et al. (1988) reported a lower value of 0.72 for the unsupplemented silage, and this increased to 0.84 on the f shmeal-containing diet. It may be that this response was related in part to the increased frequency of feeding used in the present study.

The response to fishmeal inclusion at the lower level in the present experiment (diet FM1) was below expectations and the non-linearity of response to fishmeal increments was similar to the result of Gill \& Beever (1982). Whilst undegraded dietary $\mathrm{N}$ flow to the small intestine increased in response to the extra dietary $\mathrm{N}$ supplied, microbial $\mathrm{N}$ synthesis fell more on this diet than it did on diet FM2. In attempting to reconcile this effect it is necessary to realise that in the study by Dawson et al. 1988) fishmeal was given as a supplement to grass silage, whereas in the present study fishmeal was substituted for grass silage in the total diet. Thus, Dawson et al. (1988) had an increased RDN supply $(11 \mathrm{~g} / \mathrm{d})$ and this appeared to stimulate net microbial synthesis and efficiency of RDN capture. In contrast, in the present study, RDN supplies were increased by only $3 \mathrm{~g} / \mathrm{d}$ on the two fishmeal treatments and these were accompanied by reductions in microbial protein synthesis of between 7 and $10 \mathrm{~g} / \mathrm{d}$.

Examination of these findings adds considerable support to the view that fishmeal inclusion in the diet may be exerting effects on both the rumen and post-rumen processes 
of digestion. The marked reduction in fractional outflow rate of water from the rumen with both fishmeal-containing diets supports this contention. The origin of this effect is not clear, although it may be related to the extra mineral intake associated with fishmeal feeding. It is interesting to note that recent experiments by Ortigues et al. (1989) and A. B. McAllan (personal communication) which examined fishmeal supplementation of different forage types have established similar reductions in rumen fractional outflow rates. The values for volatile fatty acid molar proportions adds further support to the suggestion of a rumen effect of fishmeal-containing diets, and whilst the overall effect on acetate +butyrate:propionate molar ratio was not large (diets $C$ and FMI 3.8 v. diet FM2 3.3), the sustained effect as illustrated in Fig. 1 appeared to be a real one.

Estimates of feed $\mathrm{N}$ degradability by both in vivo and in vitro methods are fraught with problems as no direct methods exist. However, the values in Table 4 do appear to be realistic with respect to the control silage diet, the fishmeal-containing diets and the partial degradabilities calculated for fishmeal, although it has to be recognized that the estimate of endogenous $\mathrm{N}$ flow used in the in vivo calculations could have a major effect on these calculations.

\section{Nutrient utilization}

The silage used in the present experiment was identical to that offered to young growing cattle in the production-slaughter study reported by Gill et al. (1987). Without fishmeal supplementation high levels of ad lib. intake $(24 \mathrm{~g} \mathrm{DM} / \mathrm{kg}$ body-weight) and satisfactory live weight $(0.7 \mathrm{~kg} / \mathrm{d})$ and empty-body-weight gains $(0.57 \mathrm{~kg} / \mathrm{d})$ were obtained. The silage used by Thomson et al. (1981) was also offered to growing cattle of similar initial weights at similar intake levels (C. R. Lonsdale and D. J. Thomson, unpublished results) and comparable empty-body-weight gains were observed. However, despite apparent similarities in nutrient digestion and supply, Gill et al. (1987) reported a much higher protein : fat ratio in the gain $(1.03 v .0 .55)$. Reasons for this difference are not immediately apparent.

In the study of Gill et al. (1987), fishmeal supplementation similar to the levels of substitution used in the present study gave live-weight gain responses of $0 \cdot 17$ and $0.26 \mathrm{~kg} / \mathrm{d}$ when anabolic growth promoters were not used. Values for the composition of emptybody-weight gain were obtained only for the control diet and at the highest level of fishmeal substitution, and the results indicated that virtually all the extra gain could be accounted for by increased protein retention. The actual levels of carcass $\mathrm{N}$ accretion are given in Table 6. Assuming forage-based diets have an average metabolizable energy content of $15.83 \mathrm{MJ} / \mathrm{kg}$ digestible OM intake (Ulyatt et al. 1981; Cammell et al. 1966) it may be calculated that fishmeal substitution in the present study increased total amino acid disappearance from the small intestine per unit metabolizable energy supply from $6.8 \mathrm{~g} / \mathrm{MJ}$ (diet C) to $9 \cdot 7 \mathrm{~g} / \mathrm{MJ}$ (diet FM2). Clearly the cattle responded to this increased concentration of protein in the metabolizable energy, but the responses in live weight, empty body-weight and carcass composition are in disagreement with proposals of the Agricultural Research Council (1980), which suggested that optimal absorbed protein per unit metabolizable energy requirement of a $200 \mathrm{~kg}$ steer gaining 0.75 to $1.0 \mathrm{~kg} / \mathrm{d}$ on a diet of metabolizability of 0.6 was $4.8 \mathrm{~g} / \mathrm{MJ}$. Equally Thomson et al. (1981) found similar responses in animal performance when absorbed protein supply was estimated to increase from 7.8 to 10.8 $\mathrm{g} / \mathrm{MJ}$ metabolizable energy on formalin-compared with formic acid-treated silages offered to growing cattle. In the absence of more information on the mechanisms of nutrient utilization, the discrepancy between the requirement proposed by the Agricultural Research Council (1980) and the observation that animals receiving a higher supply of protein in the basal diet were able to respond to further protein cannot be resolved. 
Table 6. The effect of fishmeal substitution ( $150 \mathrm{~g} / \mathrm{kg}$ total diet dry matter) on body nitrogen retention and the efficiency of utilization of absorbed amino acid $N$

\begin{tabular}{|c|c|c|}
\hline Diet $^{*} \ldots$ & Control & FM2 \\
\hline $\begin{array}{l}\mathrm{N} \text { intake }(\mathrm{g} / \mathrm{d})^{*} \\
\text { Amino acid } \mathrm{N} \text { absorption }(\mathrm{g} / \mathrm{d}) \dagger \\
\mathrm{N} \text { retention }(\mathrm{g} / \mathrm{d})^{*}\end{array}$ & $\begin{array}{l}76 \cdot 5 \\
37 \cdot 8 \\
15 \cdot 1\end{array}$ & $\begin{array}{r}115 \cdot 2 \\
53 \cdot 0 \\
23 \cdot 2\end{array}$ \\
\hline $\begin{array}{l}\text { Increment responses: } \\
\mathrm{N} \text { retention } \\
\text { Amino acid } \mathrm{N} \text { absorption }\end{array}$ & - & $\begin{array}{r}8 \cdot 1 \\
15 \cdot 2\end{array}$ \\
\hline Partial efficiency of amino acid $\mathrm{N}$ utilization ( $\mathrm{g}$ retained/g supplied) & - & $0 \cdot 53$ \\
\hline $\begin{array}{l}\text { Incremental responses above maintenance: } \\
\text { Amino acid } \mathrm{N} \text { available for production } \ddagger \\
\text { Efficiency of utilization of absorbed amino acid } \mathrm{N} \text { ( } \mathrm{g} \text { retained/g supplizd) }\end{array}$ & $\begin{array}{c}29 \cdot 8 \\
0.51\end{array}$ & $\begin{array}{c}45 \cdot 0 \\
0.51\end{array}$ \\
\hline
\end{tabular}

* As reported by Gill et al. (1987).

$\dagger$ Calculated from data presented in Table 5, adjusted to $\mathrm{N}$ intake reported by Gill et al. (1987).

$\ddagger$ After deduction of maintenance $N$ requirement calculated from Agricultural Research Council (1980).

Findings relating to total amino acid $\mathrm{N}$ supply, as measured in the present experiment but corrected for the differences in silage and fishmeal intakes recorded in the two studies, are also presented in Table 6 . While calculated amino acid $\mathrm{N}$ supply increased by $15.2 \mathrm{~g} / \mathrm{d}$, carcass $\mathrm{N}$ retention increased by only $8.1 \mathrm{~g} / \mathrm{d}$, suggesting a partial efficiency of utilization of the extra amino acid $\mathrm{N}$ of 0.53 . On the other hand, if body protein $\mathrm{N}$ maintenance costs are estimated on the basis of the Agricultural Research Council (1980) proposals, the utilization of amino acid $\mathrm{N}$ available for production on the two diets ( $\mathrm{C}$ and FM2) was $0 \cdot 51$. These values are surprising in two respects. First the values are all considerably less than the value of 0.75 currently adopted by the Agricultural Research Council (1980), but are in agreement with values of between 0.4 and 0.5 calculated from the studies of $C$. R. Lonsdale and D. J. Thomson (unpublished results) and Thomson et al. (1981) referred to earlier. Furthermore, it is surprising that the cattle on the zontrol diet, which on the basis of the observed production responses could be considered to be on a protein-limiting diet, did not show a higher efficiency of utilization of amino acids than the supplemented diets. On the control diet, protein deposition $(169 \mathrm{~g} / \mathrm{kg}$ empty-body-weight gain) was similar to the value of $165 \mathrm{~g} / \mathrm{kg}$ suggested by the Agricultural Research Council (1980), whilst the value for the diet with the highest level of fishmeal approached $190 \mathrm{~g} / \mathrm{kg}$, and Sanderson \& Thomas (1987) have recently reported a similar value for cattle fed on grass silage and fishmeal. These results suggest that where both total gain and protein content of that gain change in response to dietary perturbations, with a reduction in the proportional diversion of available energy into adipose tissue, empirical calculations of the efficiency of protein utilization without recognition of the underlying mechanisms may be inappropriate.

The overall effect of fishmeal substitution on the composition of the amino acid fraction absorbed from the small intestine was small despite the contribution of undegraded dietary $\mathrm{N}$ to total duodenal non-ammonia $\mathrm{N}$ increasing from $14 \%$ for $\operatorname{diet} \mathrm{C}$ to $41 \%$ for diet $\mathrm{FM} 2$. This may in part have contributed to the lack of any appc.rent increase in the efficiency of utilization of the absorbed amino acid fraction. Clearly the results do not suggest any sustained increases in the proportional contributions from methionine, which was suggested by Thomas (1982) as possibly the first limiting amino acid for growing cattle on grass-silage diets. Equally the findings for other potentially limiting amino acids, e.g. lysine, histidine and threonine, do not suggest any major improvement in potential biological value of the absorbed amino acid fraction. It is unlikely, however that specific amino acid 
deficiencies could account for the large discrepancy between the efficiency values of $0.51-0.53$ noted in the present study and 0.75 proposed by the Agricultural Research Council (1980).

In this respect, recent studies with contrasting forage:concentrate diets (Beever et al. 1988; Thomas et al. 1988) given to cattle and a predominantly barley diet fed to growing lambs (Pell et al. 1989) have indicated that the form of the energy (i.e. cereal $v$. forage) may have a major effect on the metabolic efficiency of utilization of absorbed amino acids in favour of the concentrate-enriched diets. However, this hypothesis needs to be tested before real reasons for the apparently low efficiency of absorbed amino acid utilization on foragebased diets can be elucidated.

In conclusion, the results of the present study have confirmed previous reports (Beever et al. 1977; Siddons et al. 1979; Rooke et al. 1987) that silage $\mathrm{N}$ is extensively degraded in the rumen. Consequently resultant amino acid supply is likely to limit growth in young cattle offered rations based on grass silage. Fishmeal will, at reasonably high levels of inclusion, give desirable increases in protein supply to the animal, but at lower levels of inclusion this response may be variable. The present study demonstrates that fishmeal substitution can affect rumen metabolism, although the increased molar proportion of propionate appeared to contrast with the decreased propionate production rate reported by Gill \& Beever (1982). It is clear that the animal response noted by Gill et al. (1987) was largely attributable to the increased protein supply which occurred as a result of fishmeal inclusion in the diet, but the relatively low estimates of efficiency of utilization of the absorbed amino acids on both the control and fishmeal diets is of great concern.

The authors wish to acknowledge the technical assistance provided by Messrs A. R. Austin, R. J. Barnes, D. Bozon (Nottingham University), and R. B. Marshall, M. S. Dhanoa, R. T. Evans, D. L. Gale, R. Pilgrim and Mrs J. C. Wilton. The Institute of Grassland and Animal Production is an Agricultural and Food Research Council Institute and the studies reported were commissioned by the Ministry of Agriculture, Fisheries and Food, done in conjunction with an AFRC research link with Nottingham University.

\section{REFERENCES}

Agricultural Research Council (1980). The Nutrient Requirement of Farm Livestock, no, 2, Ruminants. Farnham Royal: Commonwealth Agricultural Bureaux.

Bartram, C. G. (1987). The endogenous protein content of ruminant proximal duodenal digesta. PhD Thesis. University of Nottingham.

Beever, D. E., Cammell, S. B., Thomas, C., Spooner, M. C., Haines, M. J. \& Gale, D. L. (1988). The effect of date of cut and barley substitution on gain and on the efficiency of utilization of grass silage by growing cattle. 2 . Nutrient supply and energy partition. British Journal of Nutrition 60, 307-319.

Beever, D. E., Gill, E. M., Evans, R. T., Gale, D. L. \& Wilton, J. C. (1987). The effect of fishmeal supplementation of grass silage on nitrogen metabolism in growing cattle. Proceedings of the Nutrition Society 46, 38A.

Beever, D. E., Kellaway, R. C., Thomson, D. J., MacRae, J. C., Evans, C. C. \& Wallace, A. S. (1978). A comparison of two non-radioactive digesta marker systems for the measurement of nutrient flow at the proximal duodenum of calves. Journal of Agricultural Science, Cambridge 90, 157-163.

Beever, D. E., Thomson, D. J., Cammell, S. B. \& Harrison, D. G. (1977). The digestion by sheep of silages made with and without the addition of formaldehyde. Journal of Agricultural Science, Cambridge 88, 61-70.

Beever, D. E., Thomson, D. J., Pfeffer, E. \& Armstrong, D. G. (1971). The effect of drying and ensiling grass on its digestion in sheep. British Journal of Nutrition 26, 123-134.

Beever, D. E., Thomson, D. J., Ulyatt, M. J., Cammell, S. B. \& Spooner, M. C. (1985). The digestion of fresh perennial ryegrass (Lolium perenne L. cv. Melle) and white clover (Trifolium repens L. cv. Blanca) by growing cattle fed indoors. British Journal of Nutrition 54, 763-775.

Cammell, S. B. (1977). Equipment and techniques used for research into the intake and digestion of forages by sheep and cattle. Grassland Research Institute Technical Report no. 24. Hurley: Grassland Research Institute.

Cammell, S. B., Thomson, D. J., Beever, D. E., Haines, M. J., Dhanoa, M. S. \& Spooner, M. C. (1986). The efficiency of energy utilization in growing cattle consuming fresh perennial ryegrass and white clover. British Journal of Nutrition 55, 669-680. 
Dawson, J. M., Bruce, C. J., Buttery, P. J., Gill, M. \& Beever, D. E. (1988). Protein metabolism in the rumen of silage-fed steers; Effect of fishmeal supplementation. British Journal of INutrition 60, 339-353.

Evans, R. T., Skelton, K. V. \& Beever, D. E. (1981). Portable equipment fo: the automatic sampling of duodenal contents from housed or grazing cattle. Laboratory Practice 30, 997-1000.

Faichney, G. J. (1975). The use of markers to partition digestion within the gastro-intestinal tract of ruminants. In Digestion and Metabolism in the Ruminant, pp. 277-291 [I. W. McDonald and A. C. I. Warner, editors]. Armidale, Australia: University of New England Publishing Unit.

Gill, M. \& Beever, D. E. (1982). The effect of protein supplementation on digestion and glucose metabolism in young cattle fed silage. British Journal of Nutrition 48, 37-47.

Gill, M., Beever, D. E., Buttery, P. J., England, P., Gibb, M. J. \& Baker, R, D. (1987). The effect of oestradiol$17 \beta$ implantation on the response in voluntary intake, liveweight gain and carcass composition to fishmeal supplementation of silage offered to growing calves. Journal of Agricultural Science, Cambridge 108, 9-16.

Lonsdale, C. R. (1976). The effect of season of harvest on the utilization by young cattle of dried grass given alone or as a supplement to grass silage. $\mathrm{PhD}$ Thesis, Reading University.

McAllan, A. B., Siddons, R. C. \& Beever, D. E. (1987). The efficiency o: conversion of degraded nitrogen to microbial nitrogen in the rumen of sheep and cattle. In Feed Evaluation and Protein Requirement Systems for Ruminants, pp. 111-128 [R. Jarrige and G. Alderman, editors]. Luxemtourg: CEC.

Orskov, E. R. \& McDonald, I. (1979). The estimation of protein degradability in the rumen from incubation measurements weighted according to rate of passage. Journal of Agricultural Science, Cambridge 92, 499-503.

Ortigues, I., Smith, T., Oldham, J. D. \& Gill, M. (1989). The effects of fishmeal on growth and calorimetric efficiency in heifers offered straw-based diets. In Energy Metabolism. Proceedings of the 11th Symposium on Energy Metabolism of Farm Animals, European Association of Animal Production, Lelystad, pp. 65 -68 [Y. van der Honing and W. H. Close, editors]. Wageningen, The Netherlands: Centre for Agricultural Publishing and Documentation.

Pell, J. M., Gill, M., Beever, D. E., Jones, A. R. \& Cammell, S. B. (1989) Hormone and nutrient interaction in the control of growth: role of growth hormone and insulin-like growth factor-1. Proceedings of the Nutrition Society 48, 83A.

Rooke, J. A., Lee, N. H. \& Armstrong, D. G. (1987). The effects of intraruminal infusions of urea, casein, glucose syrup and a mixture of casein and glucose syrup on nitrogen digestion in the rumen of cattle receiving grasssilage diets. British Journal of Nutrition 57, 89-98.

Rojas, B. A. (1973). On Tukey's test of additivity. Biometrics 29, 40-52.

Sanderson, R. \& Thomas, C. (1987). Fishmeal as a supplement to grass silage fed to young cattle. Proceedings of the 8th Silage Conference, Hurley, pp. 163-164.

Siddons, R. C., Beever, D. E. \& Kaiser, A. G. (1982a). Evaluation of the effect of formic acid and level of formaldehyde application before ensiling on silage protein degradability. Journal of the Science of Food and Agriculture 33, 609-613.

Siddons, R. C., Beever, D. E. \& Nolan, J. V. (1982b). A comparison of nethods for the estimation of microbial nitrogen in duodenal digesta of sheep. British Journal of Nutrition 48, 377-389.

Siddons, R. C., Evans, R. T. \& Beever, D. E. (1979). The effect of formaldehyde treatment before ensiling on the digestion of wilted grass silage by sheep. British Journal of Nutrition 42, 535-545.

Siddons, R. C., Nolan, J. V., Beever, D. E. \& MacRae, J. C. (1985a). Nitrogen digestion and metabolism in sheep consuming diets containing contrasting forms and levels of N. British Journal of Nutrition 54, $175-187$.

Siddons, R. C., Paradine, J., Beever, D. E. \& Cornell, P. R. E. (1985b). Y terrbium acetate as a particulate phase digesta flow marker. British Journal of Nutrition 54, 509-519.

Snedecor, G. W. \& Cochran, W. G. (1969). Statistical Methods, 6th ed. Ames, Iowa : Iowa State University Press.

Thomas, C., Gibbs, B. G., Beever, D. E. \& Thurnham, B. R. (1988). The effect of date of cut and barley substitution on gain and on the efficiency of utilization of grass silage by growing cattle. I. Gains in live weight and its components. British Journal of Nutrition 60, 297-306.

Thomas, P. C. (1982). Utilization of conserved forages. In Forage Protein in Ruminant Animal Production. British Society of Animal Production Occasional Publication no. 6, pp. 67-76 [D. J. Thomson, D. E. Beever and R. G. Gunn, editors]. Thames Ditton: BSAP

Thomas, P. C., Kelly, N. C. \& Chamberlain, D. G. (1980). Silage. Proceedings of the Nutrition Society 39, 257-264.

Thomson, D. J., Beever, D. E., Lonsdale, C. R., Haines, M. J., Camm ell, S. B. \& Austin, A. R. (1981). The digestion by cattle of grass silage made with formic acid and formic acid-formaldehyde. British Journal of Nutrition 46, 193-207.

Tukey, J. W. (1955). Queries. Biometrics 11, 111-113.

Ulyatt, M. J., Beever, D. E., Thomson, D. J., Evans, R. T. \& Haines, M. J. (1981). Measurement of nutrient supply at pasture. Proceedings of the Nutrition Society 39, 67A.

Warner, A. C. I. \& Stacy, B. D. (1972). Water, sodium-potassium movements across the rumen wall of sheep. Quarterly Journal of Experimental Physiology 57, 103-119.

Wilk, M. B. \& Kempthorne, O. (1957). Non-additives in a Latin square design. American Statistical Association Journal 52, 218-236. 